Article

\title{
The Segmentation of Polish One-Person Households Due to Consumption
}

\author{
Marlena Piekut $($ i) \\ College of Economics and Social Sciences, Warsaw University of Technology, 17 Łukasiewicza St., 09-400 Płock, \\ Poland; Marlena.Piekut@pw.edu.pl or mpiekut@op.pl
}

Received: 16 October 2018; Accepted: 22 December 2018; Published: 31 December 2018

check for updates

\begin{abstract}
The scientific objective of the study was to identify consumption patterns in one-person households, living independently. The households' clusters were emerged using Ward's grouping method. It can be concluded that distinguishing the consumption patterns for one-person households is possible on the basis of diversifying both level and structure of incomes as well as socio-demographic differences between them. Depending on economic and socio-demographic variables, disparate consumption patterns for these types of households can be observed. In addition, it is worth stressing that households have different levels of income (although coming from similar sources) but similar demographic structure show greater similarity than households having similar financial situation. Both the growing number and social significance of one-person households make this research subject useful. This study contributes to understanding differences between consumption in various types of one-person households.
\end{abstract}

Keywords: one-person households; single-person households; consumption; goods; services

JEL Classification: D12; E21

\section{Introduction}

Addressing climate alteration and ecosystem problems without threatening the economy with simultaneously ensuring people's welfare seems to become considerable challenge. Up to now, a lot of the endeavor to acquire growing environmental and mankind problems has been largely outmatched in increasing consumption levels [1]. Therefore, it is increasingly important to raise awareness to the crucial motive power and complexities of consumption, and to the manner of how to reduce environmental impacts from rising consumption. This awareness can be accomplished by considering socio-demographic factors of households as well as their consumption patterns. One-person households are particularly prone to high consumption. In these households, as a rule, goods are used by one person only, while in multi-person households, one good belongs to more people.

Raising the topic was motivated by the fact that one-person households will see faster growth than any other household type globally, with around 120 million new one-person households to be added over the period 2016-2030 [2]. In 2107, every third household in the EU was held by one person.

Another motivation for writing the paper was the observation that expenditures are typically surveyed at the household level, for example, it is not possible to know the expenditure made for each household member. For example, you cannot calculate the heating expenses for each of the household members. It is the reason why the literature (in economics, sociology, and demography) usually uses some equivalent scale (Carbonaro or OECD) to make household consumption comparable across different household types. Therefore, considering expenditures in one-person households gives more accurate information on consumer behaviors, concerning exactly the person having defined socio-demographic and economic features. 
Palmer [3], Yeung and Cheung [4], Klepek and Matušínská [5], Kim, Lee, Lee [6] pointed out, that one-person households are a very heterogeneous group. They reported a high level of heterogeneity among individual one-person households. Thus, people not working or having low incomes commonly have lower standards of living and the share of basic living costs, including food, is higher than for those who have well-paid jobs and high standards of living [3]. Consequently, the one-person households require new consideration regarding the differences between them. However, so far relatively small number of attempted to the consumption patterns of one-person households.

The specific purposes of this study are as follows: (a) to explore consumption patterns in segments of one-person households; (b) to identify the characteristics of each segment; and (c) to examine the differences in consumption patterns among segments. Assessing differences in consumption patterns between one-person household segments could provide a greater understanding of these households. Consequently, this segment cannot be viewed as a uniform group of consumers, it is essential to identify, map and describe the various sub-groups (sub-segments) appropriately, including their pro-environmental behaviors.

The curiosity to learn more about one-person households became the incentive for conceptualization of both research purpose and hypothesis. The scientific objective of the study is to identify consumption patterns in one-person households.

For the purpose of evaluating the consumption patterns of these households, the following research hypotheses have been formulated:

Hypotheses 1 (H1). The significant diversification in both level and structure of income in one-person households and also socio-demographic variations between these households may serve as the basis for emergence of various consumption patterns.

Hypotheses 2 (H2). For one-person households having similar socio-demographic characteristics, regardless of their income status similar structures of expenditures on consumption goods and services are observed.

The above hypothesis can be supported theoretically in the following way. In several studies $[7,8]$ it was indicated that expenditures are determined by characteristic economic, social and demographic features of households' members. Thus, it was assumed that mentioned characteristics will make it possible to distinguish specific behaviors of the one-person households' members. It is also known, from literature sources $[9,10]$, that although income factor plays a significant role in consumer behavior, demographic-social determinants decide on specific consumption patterns.

The selection of research methods was determined by the objective of the study, proposed working hypotheses and also by characteristics of statistical data. Delimitation of household types was achieved with the methods of Ward's cluster analysis. The applied methods were suitable to achieve the objective pursued.

The growing number and social significance of one-person households make this research subject applicable. This study contributes to understanding differences between consumption in various types of one-person households.

\section{Literature Review}

The one-person household is the fastest growing type of household in many countries, because of changes in demographic behaviors in the past few decades, institutional arrangements, and labor migration [4]. For example in 2005 in Lithuania fewer than $28 \%$ of all households consisted of people who lived alone, in the same time in the Czech Republic-about $23 \%$ of all households. In 2016, that share had inched upward to $39 \%$ of all households in Lithuania and above $28 \%$ in the Czech Republic. In Poland, the share of one-person households in 2005-2016 remained at a similar level, representing 24-25\%, but according to the National Census [11], the proportion of Polish one-person households has increased in the last 4 decades, from $17.4 \%$ in 1978 to $24.0 \%$ in 2011 . The one-person households are at the moment the second most common household type just behind two-person households in 
Poland. In some European countries (e.g., Scandinavian countries, Germany), this is the most common type of households [12].

In Polish literature on the subject, the concept of one-person households is distinguished from single-person households. One-person household is a synonym for the person who lives alone in an individual, separate housing unit. This definition also includes the cases where people live independently but together with others, for example as a lodger or in a separate room. The Polish researchers $[13,14]$ defined that single-person households belong to a narrow category of one-person households, which simultaneously fulfill a few criteria meaning they are people aged between 25 to 40-45 years, childless, never been in a stable partnership, well educated and financially independent, living in big cities and having a specific lifestyle. Singles are usually people of success, they are sophisticated consumers, they value their independence and they like their lives.

Various determinants influence the increase of one-person households, including economic and socio-cultural factors, such as employment opportunities for women, individualism, late marriages, low birth rate, aging population, social consent for divorce, increase in the number of educated women, liberalization of sexual standards, and stronger government safety nets across a broad spectrum of social programs $[4,15-17]$. Another reason is the longer lives of women. According to Eurostat report in 2013, a lower proportion of men (about 14\%) were living alone than women (above 18\%). Those women live longer than their partners and therefore are more likely to live alone in old age. However, the report also reflects a lower percentage of young men (in comparison to women) choosing to leave the parental home, together with a smaller proportion of young grown-up women staying longer at home with their parent(s). In the EU-28 countries, a high share of young adults aged between $18-24$ continued living in the parental home: in 2013 , about $74 \%$ of young women and $85 \%$ of young men were living with their parent(s) [18]. The group of elderly widowed and divorced is also growing, especially, this group is remarkably large in developed countries.

People from this type of households are regarded as the ones who create new consumption culture. Newly coined-acronyms—have appeared, such as "Sindies" (Single Income Now Divorced women) and "FIT" (Free Intelligent Tribe) [19]. Furthermore, it is expected that economic contributions of one-person households will be extended. The necessity of making a business model for them was first considered at the 2007 World Economic Forum in Davos. Klinenberg [20] used the term "solo economy" for the growing economic contributions of one-person households. One-person households display tendency to excessive consumption in relation to other household types, because they have enough time and money to spend.

The increase in the numbers of one-person households may have several implications for the economy and an impact on numerous industries, ranging from health care to housing. Consumers creating one-person households express a greater demand for products of smaller package, also for products for quick preparation. Studies on food purchasing habits confirm that one-person households are more likely to opt for convenient and other "easy-to-serve and portion controlled" meal alternatives as compared to couples and families with children [21,22]. The food-related consumption behavior of one-person households is also distinctive. They tend to prefer eating out or consuming store-bought meals over cooking by themselves [23].

One-person households spend more on housing than other households and may prefer to rent, not to buy houses. When they decide to buy a house, they prefer multi-family houses rather than single-family ones. This may affect the structure of the housing market. Moreover, one-person households will have to deal with lower availability of informal personal care from the other family members. In such situation they may require purchased personal care services, in particular health and nursing care, which could significantly affect the health care industry [24].

Services occupy an important position in the one-person households expenditures. According to studies carried out for Polish single-person households, in the case of increased income, they spend additional resources on healthcare, tourist, banking and educational services. If they strive to improve housing conditions, purchase of home appliances devices, or purchase of a car, there is a place for 
activities of accompanying services [14]. As the number of one-person household enlarges, the proportion of expenditures on services is expected to increase while that on necessities such as beverage, food, and energy - to decrease. Accordingly, policy responses to this circumstance are required from government, so as to prepare for the expansion of service industries such as housekeeping, health, hospital services. In particular, companies must adopt a strategy targeted at one-person households with high income and purchasing power, such as unmarried professional people.

\section{Conception of Analysis and Preliminary Results}

The study was focused on one-person households in Poland. The research material was represented by the statistical data from individual, unpublished Central Statistic Office (CSO- Główny Urzad Statystyczny_GUS) data for household budget investigations in 2016, that covered over 37,000 households. There were 7590 one-person households in 2016. Exceptions have been removed from the database, so finally 7473 objects were qualified for the analysis.

The subject of study is to analyze consumption expenditures so as to create consumption patterns.

Statistical data analyses were conducted using Statistica 13.0. Descriptive statistics and chi-square analysis were computed on the socio-demographic characteristics. Although all the variables (12 categories in expenditures on consumption goods and services) were expressed in PLN, standardization was carried out, since this operation helped avoiding dominating classification by the highest average expenditures. Ward's grouping method make possible to establish the number of households' clusters. Ward's method deploys the analysis of variance approach to determine the distances between clusters. This method minimizes the increase of the total within-cluster sums of squares, which is also known as the error sums of squares (ESS). ESS measures the extent to which the analyzed variables in a given cluster differs from clusters mean. At the beginning of the procedure, it is assumed that each object is a separate cluster. Then the pairs of most similar clusters (with minimum between-cluster distance) are merged. At the initial step, all clusters are singletons (clusters containing a single point). This method is considered effective because it ensures the homogeneity of objects within the cluster, while the heterogeneity between clusters [25]. Then, in the dendrogram of the clustering result, the longer branches of clusters (where the distances between clusters are bigger) are cut off to obtain the optimal number of clusters.

The dendrogram was cut-off on level 65, which made six groups. According to Sagan [26], the optimum number of clusters is from 3 to 6 . The number of analyzed households in the respective clusters is given in the Table 1 . The applied criterion was the first significant leap in agglomeration distance [27]. The selected number of groups means the group preceding the first significant leap in agglomeration distance. The clustering algorithm quality has been defined on the basis of a cubic clustering criterion and a silhouette index. The value of the indices through the clusters 2 to 12 has been tested. The cubic clustering index for six clusters was $(-74.1)$, and it was the highest value among the analyzed 2 to 12 clusters, while silhouette index was 0.174 , i.e., the lowest value among the above mentioned clusters. 
Table 1. The level of available income and consumption patterns regarding the types of one-person households in Poland in 2016.

\begin{tabular}{|c|c|c|c|c|c|c|c|c|c|c|c|c|}
\hline \multirow[t]{2}{*}{ Specification } & $\begin{array}{l}\text { 1st Group } \\
\text { Average }\end{array}$ & $\begin{array}{c}\text { 2nd } \\
\text { Group } \\
\text { Poor }\end{array}$ & $\begin{array}{c}\text { 3rd } \\
\text { Group } \\
\text { Travellers }\end{array}$ & $\begin{array}{l}\text { 4th Group } \\
\text { Culture } \\
\text { Oriented }\end{array}$ & $\begin{array}{c}\text { 5th } \\
\text { Group } \\
\text { Reckless }\end{array}$ & $\begin{array}{c}\text { 6th Group } \\
\text { Health-Care } \\
\text { Oriented }\end{array}$ & $\begin{array}{l}\text { 1st Group } \\
\text { Average }\end{array}$ & $\begin{array}{c}\text { 2nd } \\
\text { Group } \\
\text { Poor }\end{array}$ & $\begin{array}{c}\text { 3rd } \\
\text { Group } \\
\text { Travellers }\end{array}$ & $\begin{array}{l}\text { 4th Group } \\
\text { Culture } \\
\text { Oriented }\end{array}$ & $\begin{array}{c}\text { 5th } \\
\text { Group } \\
\text { Reckless }\end{array}$ & $\begin{array}{c}\text { 6th Group } \\
\text { Health-Care } \\
\text { Oriented }\end{array}$ \\
\hline & \multicolumn{6}{|c|}{ Level of Expenditures in PLN } & \multicolumn{6}{|c|}{ Share of Consumption in Available Income in Percent } \\
\hline $\begin{array}{l}\text { Food and non-alcoholic } \\
\text { beverages }\end{array}$ & 443 & 346 & 337 & 484 & 394 & 452 & 25.8 & 33.5 & 12.7 & 13.3 & 24.0 & 14.4 \\
\hline $\begin{array}{l}\text { Alcoholic beverages and } \\
\text { tobacco products }\end{array}$ & 22 & 14 & 77 & 59 & 235 & 61 & 1.3 & 1.3 & 2.9 & 1.6 & 14.3 & 2.0 \\
\hline Clothing and footwear & 85 & 20 & 89 & 343 & 47 & 100 & 4.9 & 1.9 & 3.4 & 9.4 & 2.9 & 3.2 \\
\hline $\begin{array}{l}\text { Housing, water, electricity, } \\
\text { gas and other fuels }\end{array}$ & 460 & 307 & 588 & 606 & 410 & 567 & 26.8 & 29.7 & 22.2 & 16.6 & 25.0 & 18.1 \\
\hline Apartment equipment & 83 & 29 & 51 & 355 & 56 & 92 & 4.8 & 2.8 & 1.9 & 9.7 & 3.4 & 2.9 \\
\hline Health & 131 & 74 & 98 & 148 & 74 & 1153 & 7.7 & 7.2 & 3.7 & 4.0 & 4.5 & 36.8 \\
\hline Transport & 94 & 32 & 316 & 268 & 100 & 100 & 5.5 & 3.1 & 11.9 & 7.3 & 6.1 & 3.2 \\
\hline Communication & 101 & 38 & 123 & 158 & 75 & 105 & 5.9 & 3.6 & 4.6 & 4.3 & 4.6 & 3.3 \\
\hline Culture and recreation & 91 & 41 & 202 & 703 & 86 & 185 & 5.3 & 4.0 & 7.6 & 19.2 & 5.3 & 5.9 \\
\hline Education & 0 & 0 & 3 & 53 & 1 & 4 & 0.0 & 0.0 & 0.1 & 1.5 & 0.0 & 0.1 \\
\hline $\begin{array}{l}\text { Catering and } \\
\text { accommodation }\end{array}$ & 73 & 82 & 638 & 225 & 80 & 141 & 4.3 & 8.0 & 24.1 & 6.2 & 4.9 & 4.5 \\
\hline Other goods and services & 132 & 51 & 127 & 251 & 84 & 171 & 7.7 & 4.9 & 4.8 & 6.9 & 5.1 & 5.5 \\
\hline $\begin{array}{l}\text { Available income/Average } \\
\text { propensity to consume }\end{array}$ & 2113 & 1461 & 3416 & 3970 & 1997 & 2956 & 81.3 & 70.8 & 77.6 & 92.0 & 82.3 & 105.9 \\
\hline
\end{tabular}

Source: own work. 
To identify the similarity in expenditure structure between individual clusters, the Chomatowski, Sokołowski similarity measurements matrix [28] was applied. It is represented by the following formula:

$$
P_{i j}=\sum_{k=1}^{r} \min \left\{w_{i k}, w_{j k}\right\}
$$

where:

$W_{i k}$-share of in the structure in the period $i$,

$W_{j k}$-share of $k$ component in the structure in the period $j$,

$\mathrm{k}$-number assigned to $k$ component within the structure $(\mathrm{k}=1,2, \ldots, \mathrm{r})$,

$i, j$-numbers assigned to comparable structures.

For two identical structures, the similarity measurement takes the value of $100 \%$.

The significant statistical differences were tested using variance analysis. Firstly, it was verified the hypotheses assuming that averages (incomes, expenditures) for individual clusters are the same. The level of significance $\alpha=0.05$ was used. On the basis of probability value (p) the null hypothesis on equality (homogeneity) of means in respective compared groups was rejected or accepted. The value $p<0.05$ resulted in rejecting the null hypothesis. If the null hypothesis was rejected, it indicated that at least one of the clusters was different than the others and therefore in the further step for comparing differences between respective groups, post-hoc Scheffe test was applied. For more information on fundamental rules of variance analysis, see for example R.R. Sokal and F.J. Rohlf [29], S. A. Glantz, B. K. Slinker and T. B. Neilands [30].

\section{Consumption Patterns with Respect to Various Types of One-Person Households}

The grouping of one-person households made possible to distinguish six groups of these households for data coming from 2016. Two of these groups were distinctively greater than the others, which indicate two dominant consumption patterns. Consumption patterns represented by individual groups of households were the result of economic and socio-demographic features of their members.

There were no statistically significant differences $(p<0.05)$ in the level of disposable incomes between the clusters (groups) 1 and 5 . Total consumption expenditure showed statistically significant differences $(p<0.05)$ between distinguished clusters of one-person households. However, considering individual categories of consumption expenditures, it was observed that the smallest number of statistically significant differences between clusters was in expenditures on education (only in cluster 4 a statistically significant difference $(p<0.05)$ was seen) as well as in expenditures on dwelling equipment and housekeeping (statistically significant differences were noticed between cluster 4 and the others and also between 1st and 2nd clusters).

The first group ("Average") contained over $45 \%$ of one-person households. For slightly over half of them the main source of income was retirement pension, for $17.7 \%$-white-collar job and for $14.3 \%$ - disability benefit. Therefore, these households were composed of the persons aged 60 and more. $78 \%$ of these households were female ones. The people representing this cluster had usually $(41 \%)$ secondary and post-secondary education, and almost every fourth person had a college or university degree. Almost $55 \%$ of these household members were widows and widowers, and every fourth person was never-married. Almost $\frac{1}{4}$ of these households were localized in the rural areas, and the others-in urban areas of different size (Table 2). In this cluster, the expenditures on catering services and accommodation were the lowest of all. The important part of expenditure structure was clothing and footwear as well as health service needs. Relatively high were also shares of expenditures on goods and services on furnishing, telecommunication as well as other goods and services (Table 1). 
Table 2. Characteristics of the types of one-person households in Poland in 2016.

\begin{tabular}{|c|c|c|c|c|c|c|c|}
\hline Characteristics & $\begin{array}{l}\text { 1st Group } \\
\text { Average }\end{array}$ & $\begin{array}{c}\text { 2nd Group } \\
\text { Poor } \\
\end{array}$ & $\begin{array}{c}\text { 3rd Group } \\
\text { Travellers }\end{array}$ & $\begin{array}{c}\text { 4th Group } \\
\text { Culture Oriented }\end{array}$ & $\begin{array}{c}\text { 5th Group } \\
\text { Reckless }\end{array}$ & $\begin{array}{c}\text { 6th Group } \\
\text { Health-Care Oriented }\end{array}$ & Total Number \\
\hline Number of households & $\mathrm{N}=3384$ & $\mathrm{~N}=2468$ & $\mathrm{~N}=348$ & $\mathrm{~N}=306$ & $\mathrm{~N}=838$ & $\mathrm{~N}=129$ & $\mathrm{~N}=7473$ \\
\hline \multicolumn{8}{|l|}{ Gender } \\
\hline Male & 22.2 & 27.1 & 51.1 & 31.7 & 57.4 & 18.6 & 2201 \\
\hline Female & 77.8 & 72.9 & 48.9 & 68.3 & 42.6 & 81.4 & 5272 \\
\hline \multicolumn{8}{|l|}{ Age } \\
\hline Below 30 & 7.5 & 4.5 & 29.6 & 18.3 & 4.8 & $5.4^{*}$ & 570 \\
\hline $30-40$ & 6.4 & 1.8 & 15.2 & 19.9 & 6.2 & $5.4^{*}$ & 435 \\
\hline $40-50$ & 5.9 & 2.8 & 9.2 & 16.0 & 11.0 & $1.6^{*}$ & 443 \\
\hline $50-60$ & 14.6 & 13.1 & 12.6 & 13.4 & 25.2 & 10.9 & 1129 \\
\hline $60-70$ & 31.0 & 31.3 & 17.5 & 20.9 & 36.8 & 25.6 & 2288 \\
\hline Above 70 & 34.5 & 46.5 & 15.8 & 11.4 & 16.1 & 51.2 & 2608 \\
\hline \multicolumn{8}{|l|}{ Marital status } \\
\hline Unmarried, never married & 25.5 & 20.4 & 55.8 & 51.6 & 30.4 & 22.5 & 2001 \\
\hline Married & 3.7 & 2.5 & 3.7 & 4.9 & 5.1 & $2.3 *$ & 259 \\
\hline Widow, widower & 54.9 & 64.1 & 25.8 & 20.6 & 36.4 & 56.6 & 3968 \\
\hline Divorced & 14.9 & 12.0 & 14.1 & 19.9 & 26.3 & 17.8 & 1155 \\
\hline In separation & 1.1 & 1.0 & $0.9^{*}$ & $2.9^{*}$ & 1.8 & $0.8^{*}$ & 90 \\
\hline \multicolumn{8}{|l|}{ Educational level } \\
\hline $\begin{array}{l}\text { Lower secondary, primary } \\
\text { or less }\end{array}$ & 15.8 & 38.0 & 7.2 & $3.3 *$ & 16.2 & $7.0 *$ & 1652 \\
\hline Basic vocational & 19.0 & 27.3 & 8.9 & 7.2 & 32.8 & 11.6 & 1660 \\
\hline $\begin{array}{l}\text { Secondary and } \\
\text { post-secondary }\end{array}$ & 40.7 & 28.5 & 40.8 & 26.8 & 34.5 & 37.2 & 2643 \\
\hline Higher & 24.4 & 6.2 & 43.1 & 62.7 & 16.5 & 44.2 & 1518 \\
\hline
\end{tabular}


Table 2. Cont

\begin{tabular}{|c|c|c|c|c|c|c|c|}
\hline Characteristics & $\begin{array}{l}\text { 1st Group } \\
\text { Average }\end{array}$ & $\begin{array}{l}\text { 2nd Group } \\
\text { Poor }\end{array}$ & $\begin{array}{l}\text { 3rd Group } \\
\text { Travellers }\end{array}$ & $\begin{array}{c}\text { 4th Group } \\
\text { Culture Oriented }\end{array}$ & $\begin{array}{l}\text { 5th Group } \\
\text { Reckless }\end{array}$ & $\begin{array}{c}\text { 6th Group } \\
\text { Health-Care Oriented }\end{array}$ & Total Number \\
\hline \multicolumn{8}{|l|}{ Socioeconomic groups } \\
\hline $\begin{array}{c}\text { Households of blue-collar } \\
\text { workers }\end{array}$ & 7.7 & 6.3 & 10.1 & 5.2 & 17.8 & $0.8^{*}$ & 618 \\
\hline $\begin{array}{l}\text { Households of white-collar } \\
\text { workers }\end{array}$ & 17.1 & 3.8 & 38.2 & 54.6 & 16.0 & 19.4 & 1152 \\
\hline Households of farmers & 0.8 & 1.5 & $1.2 *$ & $0.3^{*}$ & 1.6 & 0.0 * & 80 \\
\hline $\begin{array}{l}\text { Households of } \\
\text { self-employed }\end{array}$ & 2.9 & 0.5 & 6.9 & 8.1 & 3.3 & $4.7^{*}$ & 191 \\
\hline Households of retirees & 51.1 & 59.2 & 26.2 & 21.9 & 37.7 & 60.5 & 3743 \\
\hline Households of pensioners & 14.3 & 18.6 & 6.0 & 3.9 & 14.4 & 11.6 & 1112 \\
\hline $\begin{array}{l}\text { Households living on } \\
\text { supplementary welfare } \\
\text { allowance }\end{array}$ & 1.8 & 6.3 & $0.6^{*}$ & $0.0^{*}$ & 5.7 & $1.6^{*}$ & 268 \\
\hline $\begin{array}{l}\text { Households having income } \\
\text { from other sources }\end{array}$ & 3.7 & 3.9 & 10.9 & 5.9 & 3.5 & $1.6^{*}$ & 309 \\
\hline \multicolumn{8}{|l|}{ Place of location } \\
\hline $\begin{array}{c}\text { Urban area, } \geq 500000 \\
\text { inhabitants }\end{array}$ & 19.8 & 13.7 & 48.0 & 39.2 & 17.3 & 33.3 & 1483 \\
\hline $\begin{array}{c}\text { Urban area, 200,000-499,000 } \\
\text { inhabitants }\end{array}$ & 12.5 & 10.1 & 10.6 & 11.4 & 11.3 & 18.6 & 864 \\
\hline $\begin{array}{l}\text { Urban area, } 200,000-499,000 \\
\text { inhabitants 100,000-199,000 } \\
\text { inhabitants }\end{array}$ & 11.2 & 8.3 & 10.3 & 10.8 & 10.7 & 10.1 & 755 \\
\hline $\begin{array}{c}\text { Urban area, 20,000-99,000 } \\
\text { inhabitants }\end{array}$ & 20.7 & 18.9 & 14.1 & 17.2 & 21.2 & 17.1 & 1470 \\
\hline $\begin{array}{l}\text { Urban area, }<20,000 \\
\text { inhabitants }\end{array}$ & 11.3 & 12.6 & 5.7 & 8.5 & 11.3 & $6.2 *$ & 840 \\
\hline Rural area & 24.5 & 36.4 & 11.5 & 12.8 & 28.0 & 14.7 & 2061 \\
\hline
\end{tabular}


The second cluster ("Poor") included 33\% of one-person households. For over $59 \%$ members of these households, the main source of income was retirement pension, for almost every fifth—disability benefits. Nearly half of the analyzed cluster were the people 70 and over, which means relatively high percentage in comparison to other clusters; and the second age group (1/3) were the people aged $60-70$. Women led nearly $\frac{3}{4}$ of these households. They were rather poorly educated ( $38 \%$ completed lower secondary school or even not) and two groups of $28 \%$ had vocational training or secondary/post-secondary education. Nearly $2 / 3$ of these household members were widows and widowers and every fifth person was never married. Over $2 / 3$ of these households were localized in small towns (up to 99 thousand of inhabitants) and rural areas. In these households, the lowest amount was allocated on almost all categories of consumption goods and services, and the level of disposable income was also the lowest. The high share (64.2\%) of expenditure on basic needs such as food and non-alcoholic beverages and dwelling maintenance determined the structure of the other expenses. In comparison to other clusters, relatively high percentage of expenditures on catering services and accommodation was noted.

The third group ("Travellers") covered $4.7 \%$ of one-person households. The majority of their members received incomes from white-collar jobs (38.2\%) and from retirement pension $(26.2 \%)$. Reasonably high fraction - nearly $1 / 3$ people forming the 3 rd cluster were under the age of 30 , i.e., they formed so-called single-person households, and more than $1 / 3$ were formed by the people at the age of 60 and over. Relatively high percentage $(10.9 \%)$ referred to the people making their living thanks to unearned sources of income. Over half of these householders were male. The people representing this cluster (nearly $84 \%$ ) had at least secondary education, and more than half had a college or university degree. As for the marital status-56\% declared being never-married, while every fourth person was divorced. There were more households (48\%) placed in cities (having over 500 thousands of dwellers) than in other clusters. Relatively high level of both disposable incomes and expenditures on transportation, catering and accommodation was noted in this cluster. Low share of expenses on food and non-alcoholic beverages $(12.7 \%)$ was observed, which probably was the result of dining out, as nearly $\frac{1}{4}$ of consumption expenditure was spent on catering services and accommodation in these households. There was also high share $(11.9 \%)$ of transportation expenses in the total structure of consumption expenditures.

The fourth cluster ("Culture oriented") was formed from $4.1 \%$ of one-person households. For over half of them the main source of income was white-collar jobs (54.6\%) for almost every five-retirement pension. $2 / 3$ of these households were female. The 4 th cluster households were formed generally by people with a college or university degree $(62.8 \%)$, but also having secondary and post-secondary education (26.8\%). Over half of these people were never married $(51.6 \%)$ and every four person declared widowhood. These households were often localized in urban areas $(87.2 \%)$, especially in cities having 500 thousand of inhabitants or more (39.2\%). In this cluster, not only the highest disposable incomes per capita but also the highest expenditures on consumption (the share of expenditures on consumption was 92\%) were observed. The highest level expenditures on food and non-alcoholic beverages, clothing and footwear, dwelling maintenance and equipment, telecommunication, culture and leisure and other consumption goods and services were noted. In the structure of expenditures the most important were expenses on goods and services connected with culture and leisure $(19.2 \%)$ and on necessary clothing and footwear.

The comparable analysis of third ("Travellers") and fourth ("Culture oriented") groups showed that gender of household head influences consumption patterns. Taking into account relatively high disposable incomes, in the male households more money was spent on catering services and accommodation, whereas in female households more money was destined for goods and services connected with culture and leisure and other consumption goods and services satisfying higher-order needs.

For the cluster fifth ("Reckless") were classified $11.2 \%$ of one-person households. The main sources of income in this group included the following: retirement pension $-37.7 \%$, blue-collar jobs $-17.8 \%$, 
white-collar jobs-16.0\%, disability benefits- $14.4 \%$. The households were usually $(62 \%)$ led by the people between the ages of 40 and 60 . Over $57 \%$ of these households were male. Their marital status was as follows: over $36 \%$-widow or widower, nearly every third-never married, and for over every fourth-divorced. Over $2 / 3$ people forming these households had vocational training or secondary/post-secondary education. These households were localized both in urban $(72.0 \%)$ and rural $(28.0 \%)$ areas. In this cluster, high level expenditures on alcoholic beverages and tobacco, and the share of these expenses in total expenditures deserves special mention.

The smallest, 6th cluster ("Health-care oriented") included $1.7 \%$ one-person households. Over $60 \%$ of these households were led by retired people and for nearly every fourth the main source of income was white-collar job. Over $\frac{3}{4}$ these household members were 60 and more. More than $81 \%$ of households were led by women and the same percentage was for people with at least secondary education. Widowhood as the marital status dominated in this cluster (57\%) and more than every fifth people were never married. These households were localized both in urban (85.3\%) and rural $(14.7 \%)$ areas. In this cluster, especially high level of expenditures on health service was observed, which is connected with high share (36.8\%) of these expenses in total expenditures. In the households of this cluster, expenditures were higher than incomes. Firstly, it may be connected with the larger priority needs in the health care what consecutively resulted in necessity of taking out a loan or credits. Secondly, it may be the consequence of income undervaluation. A literature review $[31,32]$ reveals that expenditures better than incomes illustrate living standard.

The most similar to each other-in the respect of consumption structure-were the households grouped in clusters 1 and 2 and 1 and 4 ; the similarity measure for either cluster pairs was 80.8 . As for the groups 1 and 2, both of them were similar with respect of demographic characteristics, although the education level was different in each of the groups. In the first cluster, there were more people having at least secondary education, while in cluster 2 over $65 \%$ of people had at best vocational training. Undoubtedly, the education level was the reason for higher level of disposable incomes in the first cluster. Apart from that, the similarity of demographic characteristics, such as age, gender and household location decided on similar consumption structure. As for the differences between the first and the fifth cluster, it was observed that in the first cluster dominated female households, whereas in the fifth clusters over $57 \%$ of households were male ones. Nevertheless, similar age and education level in both groups decided on similarity in consumption structure.

The greatest discrepancies were observed between the second and fourth, third and sixth clusters (similarity measure was 58.6 for each pair) and also between fourth and fifth ones (similarity measure was 56.8). For the clusters 2 and 4, the most important was the level of disposable incomes, as in the second cluster they were the lowest of all while in the fourth one-the highest of all. Moreover, the fourth cluster was formed by young, highly educated people, whereas the second cluster-by older and poorer educated people. In turn, between the third and sixth the most important were the differences in gender and age-in the third cluster was the slight predominance of younger never-married males, while in the sixth cluster was the supremacy of older women-widows. In the both abovementioned groups, over $80 \%$ of people had at least secondary education. Thus, age, gender and education level of respondents decided on important discrepancies in consumption patterns for one-person households.

\section{Discussion}

The lowest level of living of all analyzed was observed in the second cluster. The comparison of the social minimum level (in Poland social minimum is defined as a model allowing the minimum level for social integration of households) with expenditures on individual categories of goods and services [33] revealed that, for this cluster, the level of expenditures on dwelling maintenance and furnishing, clothing/footwear needs, health services and telecommunications were smaller than calculated for minimum consumer basket. The scope and level of meeting the needs, according to the standard of social minimum level should ensure at each stage of human development conditions to 
enable the reproduction of life forces, possession and education of children and the maintenance of social ties [34]. Therefore, lower level of expenditures in this group may be the indication of poverty. The analysis of demographic features implies that in the field of poverty may be found mostly the one person households of elder people (over 60) with low education level, living in the rural areas and in small towns. For these households, high share of expenditures on food in disposable income confirmed the low living standard [35] in this social group.

Both the third and fourth clusters were characterized by the highest level of living. They were embodied by people relatively young (younger than in other clusters) often never married, having a college or university degree, dwelling in larger towns. In these households high disposable incomes, low share of expenditures on food and non-alcoholic beverages and high level of expenditures on higher-order goods and services were observed. For these household consumption behaviors "for show" may be observed. Households seek to social status through consumption [36]. Symbolic consumption applies to all consumers, but plays a greater role in the group of younger ones [37]. According to the theory of social constructivism and symbolic interactionism, symbolism in consumption acquires a special meaning in the period of life changes, requiring the development of a new status, performing new roles (e.g., taking a new job or taking new contacts) [38,39]. Young people engage in a lot of effort to create a self-concept [40], hence their households are spending more on clothing and footwear. High income, a high standard of living often leads to conspicuous consumption. To change this it is necessary to change the mindset and value basis of society. In order to change this situation, it would be necessary to make different both the mindset and the basis of a system of moral values in societies [29,41].

In the study, it was proven that one-person households with the smallest income showed the highest tendency to saving, which means stronger precautionary theme than in the other groups. For these households main source of income were retirement or disability benefits. According to life-cycle hypothesis, saving tendency decreases with age. However, the obtained results demonstrate that saving tendency of older people households was larger than in the groups of younger (the 3rd and the 4 th clusters), which contradicts the abovementioned hypothesis, but testifies the results of other empirical tests [42]. The households with the smallest consumption tendency were localized mainly in rural areas. Larger saving tendency in rural households was observed also in other researches [10].

Groups of households with a dominant percentage of women had different consumption patterns from groups of households with men's domination. In male households, more money was spent on catering services. Studies show that men either take a more practical or recreational view on cooking and consume more convenience food products than women [43,44]. In female households less money was spent on alcoholic beverages and tobacco products as well as on catering and accommodation compared to male households. These results are also confirmed by studies from other countries [45-47]. The excessive consumption of alcoholic beverages, observed in male households, leads to several problems, e.g., divorces (according to CSO statistics, high alcohol use is linked to divorce for $\frac{1}{4}$ married couples after 25 years of marriage), and divorced people were found in the cluster containing people with excessive consumption of alcohol more often than in the other clusters. Moreover, alcohol and tobacco abuse is the important cause of health problems. Deaths caused by chronic liver diseases (caused inter alia by alcohol abuse) concern over $20 \%$ of male population and nearly $8 \%$ of female population in Poland [48]. This situation leads to an increase in medical expenses incurred by governments for these people. Women have greater awareness about the health effects of stimulants.

The problem of higher expenditures than received incomes, caused by high expenses of health service revealed in a part of households. The health problems could be the cause of spending savings or other forms of the household budget supplementing (loans). The out-of-pocket healthcare expenditure can be catastrophic to the household, to the point of plunging it into poverty [49], and it can arise due to basic healthcare service payments, not necessarily by reason of events that require high-cost healthcare services [50].

The created groups also differed in the age of people creating households. In the groups of households of young people, different consumption behaviors were noted in terms of the 
level and structure of expenditures. One-person households of young people invested in their intellectual development and social life, as evidenced by relatively high expenditures on education, communication, transport, catering and accommodation services. In the Euromonitor International Report [2] indicated that young people concentrate on their personal self-development, prioritizing academic and career. Women, typically have more educational and work opportunities than ever before, and many of them delays serious relationships and children. In the group formed by young people, relatively large expenditure on clothing and footwear was also observed. The choice of fashionable clothing and footwear is often a symbol of the group that young people identify with or they aspire to. Especially high expenditures on transport were noticed in households of young people with higher education. The transportation is the main source of energy consumption, pollutants, and carbon emissions. In other countries, there are recommendations to decrease the travel proportion of cars, for example through limitations on car speed, increasing bus speeds $[4,51]$.

Smaller expenditures on clothing and footwear observed in the group of elderly people are dictated by the activity of this generation. Elderly people, as a rule, are no longer professionally active, and their circle of friends is narrowing, which is why there is less opportunity to buy clothing and footwear [52]. The results of the British market research have also indicated [53] that retailers are more interested in an offer of fashionable clothing and footwear dedicated for young consumers, while they do not always understand the needs of older consumers. However, in other studies [54] the need for designing special clothes for seniors has already been noticed so as to improve the comfort and quality of their lives.

The gender and age of people creating households were also connected with expenditures for catering services. Younger people do not have sufficient time to prepare home-made meals and are more familiar with the use of (the rather less recent) ready-made meals and products [55], the author's own research confirms the observed regularity. In the group of households created mainly by women over 50 , the smallest expenditures on catering services were recorded. Ready-made meals rarely appear on the tables of this group of people, who have different cultural values and food habits than young ones [55]. However, the lifestyle of seniors is changing, among others by the dynamic development of medical services. The stereotypical image of lonely and poor elderly people is slowly replaced with the image of active people, with a hedonistic approach to life [56].

The high level of expenditure on catering services and their high share in available income has its roots in the social background. The research conducted among the Swedes showed that the one-person households consider cooking and consuming food alone mostly as having only one intention-moderating hunger. The singles say that boring and uninspiring is cooking and eating food alone. In addition, they stress the presence of different social factors as regards their food consumption. Take-away food and eating out is regarded as a fundamental part of the singles' food consumption, not as a way of give themselves pleasure [57]. The recent trend of the growing number of one-person households may help in the development of the catering industry [23]. Although the financial cost of self-prepared meals is higher for singles (unless they prepare some portions in advance for later use), they have to spend about the same time to get their meals ready as to multi-person households [58]. Generally, in one-person households were noted larger expenditures for catering services and accommodation than in multi-person households. One-person households are clearly less likely to perceive cooking as an important social duty and a symbol of family life than families with children [55].

Among the households grouped in the third and fourth clusters, a high level of housing, water, electricity, gas and other fuels expenditure was observed. These are households located mainly in large cities. In other studies, it is emphasized that large houses located in the rural area generate high maintenance costs. The research shows that the flats/houses kept by people from one-person households in cities are larger than in the countryside. It may be caused by better financial situation of households located in cities. Another researcher has also pointed that in the long run, an increase of $1 \%$ in GDP at current prices in Lithuania will lead to an increase of above $0.53 \%$ in electricity consumption 
per capita [59]. It can be assumed the results of this research can contribute to promotion of electricity saving aligned with the changes in demographic and social situation also in Poland.

\section{Conclusions}

For more over ten years, on average, every fourth household in Poland is a one-person household. However, it is observed that the share of one-person households in general number of households has increased significantly since the second half of the twentieth century. Due to this phenomenon, the need arises to acquire more insight into their consumer behavior and standard of living.

One-person households are formed by heterogeneous consumer groups. Polish one-person household were classified into six groups, with two groups considerably larger than the others. Younger one-person household members had larger incomes than older ones. As for the expenditure structure, for clusters in which there is a majority of female households, larger expenditure on clothing, footwear and dwelling equipment, while in male households-on transportation, catering services and accommodation. It means that women invest in goods that help them to stand out from the crowd: fashionable clothes, modern apartment. Men, in turn, are more interested in services and means of transportation, which is connected with comfort. Men spend more money on alcoholic beverages and tobacco products. These products negatively affect their health, so it is necessary to prepare suitable public awareness campaign for this group of people. For a part of older one-person households (over 70) extremely high expenditures on health services were observed. In these households expenditures on consumption goods and services were higher than their disposable incomes, which indicates unfavorable situation in this group and the need of welfare centers involvement.

Socio-demographic features influence consumption structure of one-person households. It has been noted that higher income level (the first and second clusters) and higher education level make larger consumers of services (telecommunication, culture and leisure) and create larger expenditures on goods combined with standing out (clothing-footwear goods, furnishing, and household equipment).

In general, it can be concluded that distinguishing the consumption patterns for one-person households is possible on the basis of diversification both level and structure of incomes in these households as well as socio-demographic differences between them. Depending on economic and socio-demographic variables, disparate consumption patterns for these types of households can be observed. Thus, the Hypothesis 1 has been confirmed. In addition, it is worth stressing that household having different level of income (although coming from similar source) but similar demographic structure show greater similarity than households having similar financial situation. This observation proves the Hypothesis 2.

This paper contributes to better understanding of heterogeneity amongst one-person households. Better insight into particular segments of market makes possible (for management of economic entities) to adjust offered goods and services to demands of these consumers.

As for the further research, it seems to be worth establishing the diagnosis for consumption patterns in other types of households. These results could be compared with consumption patterns presented above. Since the number of published researches on segmentation of one-person households is small, the analysis of this issue with regard to individual countries is also worth consideration. A greater number of such data may become the basis for comparative analyses and conclusions concerning this new emerging market segment. As for the future research, the attempts to understanding the results of these market segments may be useful for economic policy and company managers.

Funding: The study was financed from the budget of the city of Płock in connection with the Competition of the President of the City of Płock for financing research grants carried out as part of the task "Cooperation with universities".

Acknowledgments: I am grateful to the suggestions and insightful comments of three anonymous reviewers, and the financial assistance by the President of the City of Płock.

Conflicts of Interest: The author declares no conflict of interest. 


\section{References}

1. Mont, O.; Power, K. The role of formal and informal forces in shaping consumption and implications for a sustainable society. Part I. Sustainability 2010, 2, 2232-2252. [CrossRef]

2. The Future Consumer Households in 2030. Euromonitor International. Available online: http:/ / go.euromonitor. com/rs/805-KOK-719/images/sbFutureConsumerHouseholds2030.pdf (accessed on 12 September 2018).

3. Palmer, G. Single Person Households. Joseph Rowntree Foundation, New Policy Institute, 2006. Available online: https:/ / www.npi.org.uk/files/4213/7544/5585/single_people.pdf (accessed on 10 September 2018).

4. Yeung, W.J.J.; Cheung, A.K.L. Living alone: One-person households in Asia. Demogr. Res. 2015, 32, $1099-1112$. [CrossRef]

5. Klepek, M.; Matušínská, K. Purchasing behaviour of czech singles and its consequences on marketing communication effectiveness. Acta Acad. Karviniensia 2016, 1, 57-69.

6. Kim, S.; Lee, K.; Lee, Y. Selection attributes of home meal replacement by food-related lifestyles of single-person households in South Korea. Food Qual. Prefer. 2018, 66, 44-51. [CrossRef]

7. Rosella, L.C.; Fitzpatrick, T.; Wodchis, W.P.; Calzavara, A.; Manson, H.; Goel, V. High-cost health care users in Ontario, Canada: Demographic, socio-economic, and health status characteristics. BMC Health Serv. Res. 2014, 14, 532. [CrossRef] [PubMed]

8. Jones, R.V.; Fuertes, A.; Lomas, K.J. The socio-economic, dwelling and appliance related factors affecting electricity consumption in domestic buildings. Renew. Sustain. Energy Rev. 2015, 43, 901-917. [CrossRef]

9. Babicz-Zielińska, E.; Jeżewska-Zychowicz, M. Wpływ czynników środowiskowych na wybór i spożycie żywności. Handel Wewnętrzny 2015, 2, 5-18.

10. Piekut, M. Wzorce Konsumpcji Wedtug Typów Wiejskich Gospodarstw Domowych W Latach 2004-2014; Difin: Warszawa, Poland, 2017; ISBN 978-83-8085-419-2.

11. CSO. National Census 2011; CSO: Warsaw, Poland, 2014.

12. Eurostat Database 2018. Distribution of Households by Household Size-EU-SILC Survey. Available online: http:/ / appsso.eurostat.ec.europa.eu/nui/setupDownloads.do (accessed on 10 September 2018).

13. Czernecka, J. Polscy single jako konsumenci: Dziś i jutro. Acta Universitatis Lodziensis. Folia Oeconomica 2009, 231, 171-184. (In Polish)

14. Dąbrowska, A.; Janoś-Kresło, M. Single jako konsumenci usług rynkowych ze szczególnym uwzględnieniem usług turystycznych. Zeszyty Naukowe Uniwersytetu Szczecińskiego. Problemy Zarządzania, Finansów i Marketingu 2011, 22, 377-388. (In Polish)

15. Bennet, J.; Dixon, M. Single Person Households and Social Policy-Looking Forward; Joseph Rowntree Foundation: York, UK, 2006; pp. 1-47.

16. Buunk, B.; van Driel, B. Variant Lifestyles and Relationships; Sage Publications: Thousand Oaks, CA, USA, 1989.

17. Szukalski, P. Przemiany rodziny-Wyzwania dla polityki rodzinnej. Artykuł dyskusyjny. Polityka Społeczna 2007, 8, 50-53. (In Polish)

18. People in the EU-Statistics on Household and Family Structures. Eurostat, Statistics Explaind, 2015. Available online: https:/ / ec.europa.eu/eurostat/statistics-explained/index.php?oldid=237801 (accessed on 8 September 2018).

19. Kim, H.Y. Floating families in Korea: Focusing on one-person households. J. Korean Soc. 2014, 15, $255-292$.

20. Klinenberg, E. I want to be alone: The rise and rise of solo living. Guardian 2012, 30, 41-43.

21. Candel, M. Consumers' convenience orientation towards meal preparation. Conceptualization and measurement. Appetite 2001, 36, 15-28. [CrossRef] [PubMed]

22. Harris, J.M.; Shiptsova, R. Consumer demand for convenience foods. Demographics and expenditures. J. Food Distrib. Res 2007, 38, 22-36.

23. Jo, P.K. The Effects of the Economic Characteristics of Single-person Households on the Food Service Industry. Korean J. Community Nutr. 2016, 21, 321-331. [CrossRef]

24. Bachman, D.; Barua, A. Single-Person Households: Another Look at the Changing American Family. Deloitte. Insights. Available online: https:/ / www2.deloitte.com/insights/us/en/economy/behind-the-numbers / single-person-households-and-changing-american-family.html (accessed on 10 September 2018).

25. Ward, J.H., Jr. Hierarchical grouping to optimize an objective function. J. Am. Stat. Assoc. 1963, 58, $236-244$. [CrossRef] 
26. Sagan, A. Metody Statystyczne w Marketingu i Badaniach Rynku; Materiały Szkoleniowe StatSoft w Ramach Kursu Obsługi Programu Statistica, Krakov, Statsoft: Kraków, Poland, 2010.

27. Sokołowski, A. Empiryczne testy istotności w taksonomii. Zeszyty Naukowe Akademia Ekonomiczna w Krakowie. Seria Specjalna, Monografie 1992, 108, 105. (In Polish)

28. Chomatowski, S.; Sokołowski, A. Taksonomia struktur. Przegląd Statystyczny 1978, 2, 217-226.

29. Sokal, R.R.; Rohlf, F.J. The Principles and Practice of Statistics in Biological Research; WH Freeman and Company: San Francisco, CA, USA, 1969; pp. 399-400.

30. Glantz, S.A.; Slinker, B.K.; Neilands, T.B. Primer of Applied Regression and Analysis of Variance; McGraw-Hill: New York, NY, USA, 1990; Volume 309.

31. Blundell, R.; Preston, I. Consumption inequality and income uncertainty. Q. J. Econ. 1998, 113, 603-640. [CrossRef]

32. Meyer, B.D.; Sullivan, J.X. Consumption and Income Inequality in the US Since the 1960s. Natl. Bur. Econ. Res. 2017. [CrossRef]

33. Kurowski, P. Minimum socjalne w 2016 r.: Dane średnioroczne. Polityka Społeczna 2017, 9, 30-31.

34. Deniszczuk, L. Kilka uwag o historii i funkcjach minimum socjalnego. Polityka Społeczna 2001, 11-12, 5-6.

35. Kusińska, A.; Olejniczuk-Merta, A. Konsumpcja w Polsce 2000-2007; IBRKiK: Warszawa, Poland, 2008.

36. Charron-Chénier, R. Spending Bundles: Incorporating Household Expenditures in the Sociology of Consumption. Socius 2018, 4. [CrossRef]

37. Isaksen, K.J.; Roper, S. The Commodification of Self-Esteem: Branding and British Teenagers. Psychol. Market. 2012, 29, 117-135. [CrossRef]

38. Leigh, J.H.; Gabel, T.G. Symbolic Interactionism: Its Effects on Consumer Behaviour and Implications for Marketing Strategy. J. Consum. Market. 1992, 9, 5-16. [CrossRef]

39. Solomon, M.R. The Role of Products as Social Stimuli: A Symbolic Interactionism Perspective. J. Consum. Res. 1983, 10, 319-329. [CrossRef]

40. Piacentini, M.; Mailer, G. Symbolic consumption in teenagers' clothing choices. J. Consum. Behav. 2004, 3, 251-262. [CrossRef]

41. Meadows, D. Leverage Points: Places to Intervene in a System; The Sustainability Institute: Hartland, VT, USA, 2006; Available online: http:/ / racialequitytools.org/resourcefiles/donellameadows.org-Leverage_Points_ Places_to_Intervene_in_a_System.pdf (accessed on 5 September 2018).

42. Rószkiewicz, M. Oszczędzanie: Postawy i Zachowania Polskich Gospodarstw Domowych Wobec Oszczędzania; Wydawnictwo Aureus: Kraków, Poland, 2008; ISBN 978-8360741115.

43. Aarseth, H.; Olsen, B.M. Food and masculinity in dual-career couples. J. Gend. Stud. 2008, 17, $277-287$. [CrossRef]

44. Brunner, T.A.; Van der Horst, K.; Siegrist, M. Convenience food products. Drivers for consumption. Appetite 2010, 55, 498-506. [CrossRef]

45. Bilgic, A.; Yen, S.T. Household Alcohol and Tobacco Expenditures in Turkey: A Sample-Selection System Approach. Contemp. Econ. Policy 2015, 33, 571-585. [CrossRef]

46. Changpetch, P.; Haughton, D.; Le, M.; Ly, S.; Nguyen, P.; Thach, T. Alcohol consumption in Thailand: A study of the associations between alcohol, tobacco, gambling, and demographic factors. Asian J. Soc. Sci. Humanit. 2016, 5, 53-67. [CrossRef]

47. Egan, K.; Jørgensen, M.; Becker, U.; Tolstrup, J. Alcohol consumption, educational level and labour market participation: A prospective cohort study of transitions between work and unemployment. Revue d'Épidémiologie et de Santé Publique 2018, 66, S367. [CrossRef]

48. Paciaj, P.; Ciabiada, B.; Bryła, M.; Maniecka-Bryła, I. Spożycie alkoholu a natężenie umieralności z powodu przewlekłych chorób wątroby w populacji polskiej. In Problemy i Perspektywy Zarzadzania w Społeczeństwie Ryzyka Oraz Zagadnienia Jakości Życia; Depta, A., Ed.; Monografie Politechniki Łódzkiej: Łódź, Poland, 2016.

49. Wagstaff, A.; Doorslaer, E.V. Catastrophe and impoverishment in paying for health care: With applications to Vietnam 1993-1998. Health Econ. 2003, 12, 921-933. [CrossRef] [PubMed]

50. Sesma, S.; Pérez, R.; Gómez, O. Síntesis Ejecutiva: Magnitud y Origen de los Gastos Catastróficos por Motivos de Salud por Entidad Federativa: México 2002-2003; Secretaría de Salud de México: México City, Mexico, 2004.

51. Wang, B.; Shao, C.; Ji, X. Influencing mechanism analysis of holiday activity-travel patterns on transportation energy consumption and emissions in China. Energies 2017, 10, 897. [CrossRef] 
52. Piekut, M. Gdzie tkwi potencjał wzrostu popytu? Wydatki na odzież i obuwie w polskich gospodarstwach domowych. Edukacja Ekonomistów i Menedżerów 2016, 2, 165-182.

53. Birtwistle, G.; Tsim, C. Consumer purchasing behaviour: An investigation of the UK mature women's clothing market. J. Consum. Behav. 2005, 4, 453-464. [CrossRef]

54. Palamutcu, S.; Goren, I. Functional Textile Preferences of Elderly People. Mediterr. J. Soc. Sci. 2015, 6, 279. [CrossRef]

55. Daniels, S.; Glorieux, I.; Minnen, J.; Van Tienoven, T.P. More than preparing a meal? Concerning the meanings of home cooking. Appetite 2012, 58, 1050-1056. [CrossRef]

56. Zalega, T. Incomes and savings of Polish seniors in view of research outcomes. Problemy Zarzadzania 2016, 14, 135-155. [CrossRef]

57. Tenmann, E.V. Husholdningenes Konsum i Nasjonalregnskapet. Beregning av Konsumnivået for 2012 med Utgangspunkt i nye Kilder. Magisteruppsats 10 Poäng. Företagsekonomiska institutionen, Stockholms Universitet, 2016. Available online: https://brage.bibsys.no/xmlui/handle/11250/2461199 (accessed on 15 September 2018).

58. Daniels, S.; Glorieux, I. Convenience, food and family lives. A socio-typological study of household food expenditures in 21st-century Belgium. Appetite 2015, 94, 54-61. [CrossRef]

59. Vojtovic, S.; Stundziene, A.; Kontautiene, R. The Impact of Socio-Economic Indicators on Sustainable Consumption of Domestic Electricity in Lithuania. Sustainability 2018, 10, 162. [CrossRef]

(C) 2018 by the author. Licensee MDPI, Basel, Switzerland. This article is an open access article distributed under the terms and conditions of the Creative Commons Attribution (CC BY) license (http://creativecommons.org/licenses/by/4.0/). 